\title{
A MODEL TO LINK TAKT SCHEDULES AND OPERATIONS IN CONSTRUCTION
}

\author{
Jon Lerche ${ }^{1}$ Hasse Neve $^{2}$, Allan Gross ${ }^{3}$, and Søren Wandahl ${ }^{4}$
}

\begin{abstract}
This research paper presents a model for construction that can bridge the gap between the schedules (takt planning or location-based management) and the on-site operations using visual management (VM). The model was developed using design science. It was shaped in a modular construction environment and evaluated theoretically. The knowledge base consists of; takt planning, location-based scheduling (LBS), plan-do-check-act, and visual management. The evaluation of the model revealed that a generic model could accommodate both schedule methods and incorporate continuous learning. The discussion provided knowledge about the industrial implication and how managers could apply this in Takt or LBS planned and controlled projects. This research further contributes to the literature by extending the existing knowledge of scheduling and visual management.
\end{abstract}

\section{KEYWORDS}

Design science, location-based management (LBM), takt planning (TP), visual management, work structuring.

\section{INTRODUCTION}

Visual Management (VM) in construction has taken different forms through the years (Tezel et al. 2016), Leth et al. (2019) revealed how it is applicable on a strategic level when implementing "hoshin kanri" in mega projects. Different models of VM have been investigated in various case studies, revealing the industry implications and numerous visual expressions (Valente et al. 2016). Valente et al. (2017) found that VM systems tend to be static, lack process transparency, and fail to involve the workers performing the tasks. Finding less than $5 \%$ had created a link between the planning function and the visual expression. Reinbold et al. (2020) support this and expand how it affects decisionmaking among managers and workers - revealing a gap in understanding how to include VM with a planning function that engages and encourages learning among the actors. This research was further motivated by the stagnation of labor productivity within construction (Neve et al. 2020) and that Lerche et al. (2020) showed how VM led to increases in productivity.

$1 \mathrm{PhD}$, Dept. of BTech., Aarhus University, Birk Centerpark 15, 7400 Herning, Denmark, jon.lerche@ btech.au.dk, orcid.org/0000-0001-7076-9630

2 PhD, Consultant, Denmark, hasse_neve@hotmail.com, orcid.org/0000-0003-2311-3529

3 Professor, Dept. of BTech., Aarhus University, Birk Centerpark 15, 7400 Herning, Denmark, agr@btech.au.dk

4 Professor, Aarhus University, Dept. of Technology Management \& Engineering, Inge Lehmanns Gade 10, 8000 Aarhus C, Denmark, swa@cae.au.dk, orcid.org/0000-0001-8708-6035 
The literature review made it evident that multiple case studies present implementation of $\mathrm{VM}$ in numerous expressions and also in relation to different planning methods such as Takt at operators level in modular construction (Lerche et al. 2019; Lerche et al. 2020), Mariz et al. (2019) used VM to visualize Kanban for planning the construction of a dam. (Brandalise et al. 2018) used VM for Kanban combined with a performance board, where Farzad and Cameron (2019) used it for deliverable matrixes. Wesz et al. (2018) presented a complete project VM adaption of Last Planner System (LPS) (Ballard 2000), and Mota et al. (2019) instead defined the VM as part of the collaborative planning alone. Jabbari et al. (2020); Singh et al. (2020), on the other hand, presented digital solutions for organizing Takt zones according to work density without practical application. Despite Takt and Kanban being seen as part of VM models, limited knowledge exists of these combined as part of a VM model on project levels. These findings reveal a gap in the body of knowledge, where a model accommodating practical applications for takt planning or LBS at the project level could contribute.

The objectives of this research are to provide a production model which accommodates the following:

- facilitates interaction between managers and workers,

- practical application of takt planning or LBS at the project level,

- provides a clear overview of activities and labor resources.

As this research project is within the design science domain, the paper has the following structure to meet the objectives. First, the introduction frames the problem, the background the presents the literature review, and the method that describes the research framework. The results then present the model and its theoretical adoption, leading to the evaluation and discussion of its relevance to the literature, and finally, the conclusion reveals the potential implications.

\section{BACKGROUND}

The artifact is composed of the knowledge base, and it is meant to improve the application of Takt and LBS in a construction environment. Hence, the background displays Takt and LBS's topics as the planning methods, second the visual management, and third the learning culture. Together these topics form the knowledge base.

\section{Takt Planning and Location-Based Scheduling}

When graphically presented, Takt planning and location-based scheduling (LBS) both rely on tasks moving through locations or designated space (production areas), generating a continuous visual flow, strengthening the focus on the flow of operations and processes. Within each project, the location structures can be determined according to workload, which applies to both LBS (Lerche et al. 2019; Lerche et al. 2019) and Takt (Jabbari et al. 2020; Lehtovaara et al. 2019; Singh et al. 2020), in particular, the Takt time as described by Frandson and Tommelein (2016).

When Frandson et al. (2015) compared Takt and LBS, they found them to have similar capabilities;

- continuous flow production areas

- ability to trade scope

The two methods differentiate when it comes to buffering and controlling; first, we address the four buffer types listed here; 1. Time, 2. Capacity, 3. Space, and 4. plan buffers. 
For buffering, LBS utilizes 1,3, and 4, whereas Takt utilizes 2,3, and 4. Takt further underload the activities, creating a capacity buffer. For controlling the takt and LBS, Frandson et al. (2015) argue LBS to have a more engineered approach and decentralized approach, where Takt relies on verifying the actual area completion.

\section{ViSUAL MANAGEMENT}

Visual management on a construction site is not limited to visual boards, it also encompasses visual aids in the environment (Brady et al. 2012; Brandalise et al. 2018; Farzad and Cameron 2019; Reinbold et al. 2020; Tezel et al. 2016; Tezel et al. 2011; Valente et al. 2016; Wesz et al. 2018), our focus here is on VM production boards or models. According to Tezel et al. (2016), VM has nine functions in total, mentioned here below;

- "Discipline,"

- "On-the-job training (OJT),"

- "Job facilitation,"

- "Process transparency,"

- "Continuous improvement,"

- "Management-by-facts,"

- "Simplification,"

- "Creating a shared ownership and the desired image," and

- "Unification and creating a boundaryless organization."

1,2 and 3 are related to the behavior of the managers and workers, 4,5,6 and 7 are associated with the structure of the processes and plan, 8 and 9 are related to the organizational values. Fiallo $\mathrm{C}$ and Howell (2012) focused on 4, 6, and 7 when they presented project drawings as part of the Takt plan to better overview workers. Tezel et al. (2010) supports this and stretch the importance of making VM accessible in the proximity of the area needed, which further supports Tezel et al. (2013) finding that VM could increase project safety by tracking workers who are working in or around hazardous environments.

\section{CONTINUOUS LEARNING AND IMPROVEMENT}

Whether seen in production or construction, the Deming cycle of Plan-Do-Check-Act (PDCA) is a method to ensure management of quality through continuous improvements (Deming 2000; Koskela et al. 2019). The direct link to the plan is part of the iterative process, which keeps repeating while striving towards perfection. The PDCA model function in a corporation with a production planning or control method was seen with LPS (Ballard and Tommelein 2016), utilized to prevent deviations from occurring. Lerche et al. (2019) showed similar approach incorporation with Takt planning. Although the PDCA method has been available for almost a century, there is to our understanding still limited knowledge of how to combine it in a practical application with LBS.

\section{METHOD}

This research project follows the design science framework from Hevner et al. (2004), similar to what was utilized in Lerche et al. (2020). Both Baskerville (2008) and van Aken et al. (2016) approve this approach in an operations management setting. Figure 1 shows 
the framework used to develop the model. Based on the knowledge base on the left side, the model becomes an artifact (Simon 1996). For finalization and implementation, industry experts from a given project are to further shape is based on the right side of Figure 1 knowledge of the environment.

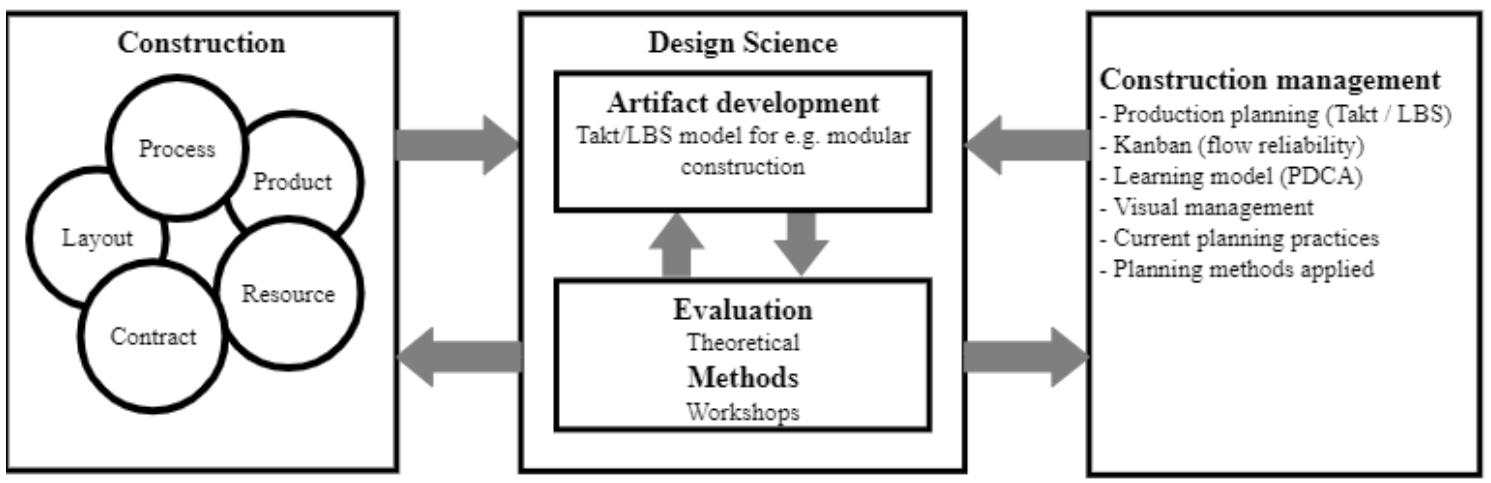

Figure 1. Framework for model development.

The research project had the following sequence, similar to what Rocha et al. (2012) presented;

1. frame the problem from the industry and literature,

2. the knowledge base was developed through a literature review, searching visual management, Takt, LBS, learning culture,

3. the model was developed based on the knowledge base and past planning applications

4. the model was adjusted and evaluated through three workshops held with part of a project team (a site manager, a supervisor, two foremen, and two technicians) from a modular construction site in the United Kingdom,

5. the model was theoretically evaluated based on its functions (Tezel et al. 2016) and ability to:

a) facilitate learning and engagement of both managers and operators

b) accommodate both LBS and Takt planning

c) visualize the plan (processes) and labor resources effectively

d) operate through a given set of rules

By following this approach, we differentiate from action research, as also argued by Järvinen (2007). We do not seek to develop or find a model which only applies in one given context but conceptualize it for a broader application purpose.

\section{ARTEFACT FOR VISUAL TAKT AND LBS MODEL}

\section{INNER ENVIRONMENT}

The key elements of the inner environment consist of the tasks, resources, an area for listing deviations and actions, and an area for the key safety and quality issues. The tasks are organized according to the Takt or LBS schedule. This also applies to the resources, for the resources picture cards or name signs are intended. When tasks and resources are organized, the operational rules are as follows. The resource marking under each task illustrates the required number of operators by a change in colors, white being the minimum, a grey color illustrating the potential for ramp-up, black representing the upper limit for resources. 
The artifact works with a magnet representing the location or module is being moved across the board from left to right, starting by positioning a magnet with a location tag attached in a). When operations are started, the magnet is moved into b) while the work ongoing or determined Work in Progress (WIP). When the Takt or process has been completed, the location magnet is placed in c), when the succeeding task is ready for the location magnet, it is pulled into b) task 2 and so forth. Meaning that the location moves a) to task $1 \mathrm{~b}$ ), when finished, it moves task $1 \mathrm{c}$ ). When task 2 is ready, it moves to task 2 b), when finished, it moves to c). These steps continue until the location magnet reaches d), which is an overview drawing of the final location as seen in, e.g. (Jabbari et al. 2020; Singh et al. 2020) or (Frandson and Tommelein 2016). This overview drawing should be detailed enough for workers to identify the zones. The magnet functions as a production card from Kanban (Hopp and Spearman 2004), representing the operation from Lehtovaara et al. (2020) moving through process steps. The magnet is not to be moved randomly but must follow the organized Takt as in a Kanban system.

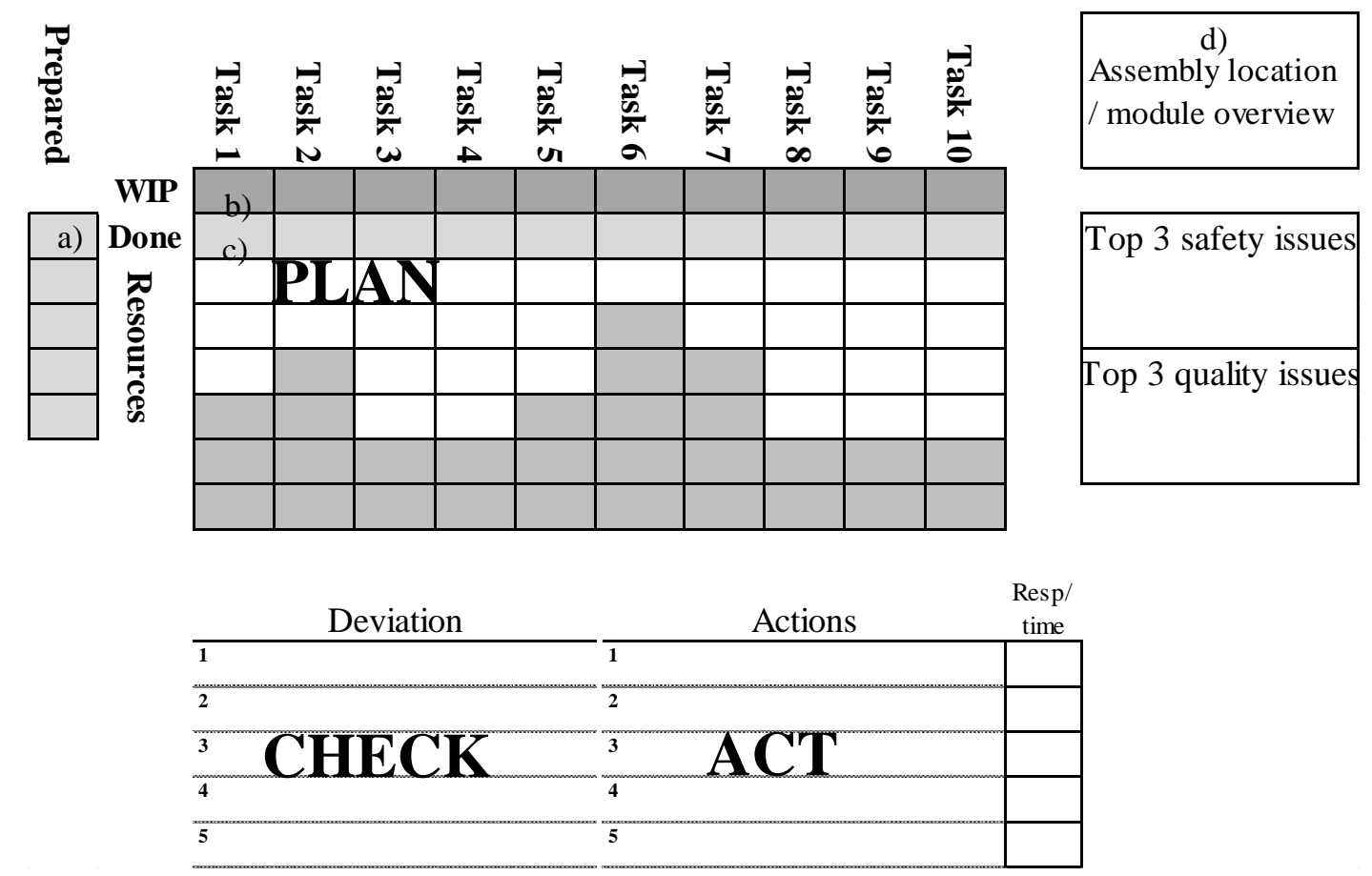

Figure 2: Key elements for artifact

Plan, Check, Act is another layer of key elements in this artifact. The list of deviations (check) shows the current daily issues, and the action list (act) reveals how workers and managers will solve these issues. Ballard and Tommelein (2016) described 5 Why's should be used to make use of the deviations and prevent reoccurrence of issues. Reoccurring issues are intended to be uplifted to either the top 3 safety or quality issues. This could be expanded with graphs showing preconditions that are not met (Lindhard and Wandahl 2012; Lindhard and Wandahl 2014).

\section{INTERFACE TOWARDS THE OUTER ENVIRONMENT}

The visual impression is interfacing towards the outer environment. It requires an understanding of organizing the tasks, the labor resources in accordance with the sequence from the designed plan. Figure 2 can be visualized as a whiteboard design. The additional board configurations for this application could have a lower quadrant prepared 
for off-shift workers and management picture cards. These picture cards of workers would further be used to show who is working and where. Between the area b) and the task could be where a time measure is placed for each task completion. If the process requires it, a buffer between tasks/ process steps could protect the flow. For modular wind construction, this was used to protect the crane activities to keep a continuous flow. As seen in Lerche et al. (2020), an implementation and communication plan would be required to enable the connection between the artifact and the outer environment. Tezel et al. (2016) support this, arguing that it is necessary to create organizational connections to the VM aid.

\section{Evaluation}

Table 1 shows the evaluation of the model by using the functions from Tezel et al. (2016). It was not considered relevant to evaluate 8) and 9) as these were related to the organization and thereby the outer environment implementation.

Table 1: Evaluation of the model's visual management functions.

\begin{tabular}{|c|c|}
\hline Functions & Evaluation \\
\hline 1. Discipline & $\begin{array}{l}\text { The magnet route encourages discipline among managers and workers, } \\
\text { as it will be visual to all if the sequence is neglected or ignored. }\end{array}$ \\
\hline $\begin{array}{l}\text { 2. On-the-job } \\
\text { training }\end{array}$ & $\begin{array}{l}\text { This has not been evaluated, but the simplicity and overview could be } \\
\text { considered enabling factors. The resource cards allow individuals to be } \\
\text { easily identified in case help etc., is needed. }\end{array}$ \\
\hline 3. Job facilitation & $\begin{array}{c}\text { The artifact allows through its usage of magnets to display where teams } \\
\text { are located, not only for managers or other workers but also for visitors } \\
\text { with limited knowledge of the progress. }\end{array}$ \\
\hline $\begin{array}{l}\text { 4. Process } \\
\text { transparency }\end{array}$ & $\begin{array}{c}\text { Tasks and locations are visible to all actors involved, bottlenecks and } \\
\text { queuing }\end{array}$ \\
\hline $\begin{array}{l}\text { 5. Continuous } \\
\text { improvement }\end{array}$ & $\begin{array}{c}\text { The PDCA continuously allows managers and workers to engage in } \\
\text { knowledge sharing, assess deviations and actions directly related to the } \\
\text { production. Enabling this. }\end{array}$ \\
\hline $\begin{array}{l}\text { 6. Management- } \\
\text { by-facts }\end{array}$ & $\begin{array}{l}\text { Both } 5 \text { and } 7 \text { contribute to this function, as everything is available for the } \\
\text { decision-makers, top } 3 \text { functions further support this. }\end{array}$ \\
\hline 7. Simplification & The direct link between the plan, process, resources, and location \\
\hline
\end{tabular}

\section{DISCUSSION}

The artifact was developed in a modular construction environment accommodating both takt and LBM scheduling, created as a visual expression of the who, what, when, and where. Providing managers and workers with a visual overview of the plan (processes), resources, its deviations, and outstanding actions, Lerche et al. (2019); Lerche et al. (2020) showed how this approach allowed productivity improvements up to $50 \%$ on operators level, as the inputs remained consistent, but the throughput time was reduced. Lerche et al. (2019); Lerche et al. (2020) also revealed the combination of takt and PDCA at the operator level. Our findings here expand on this and extend the body of knowledge by creating a model for practical application of LBS and takt at the project level. Furthermore, this also reveals the model's potential usefulness. 


\section{TAKT AND LBS PRODUCTION IMPLICATIONS}

Frandson et al. (2015) argued that, for controlling Takt and LPS to be different, the artifact presents a unified method for controlling tasks and resources independent of the planning method. The magnet rules and movement further provide the involved parties and external parties with a clear overview of process status and visualizes potential bottlenecks if such should occur. Frandson and Tommelein (2016) presented a field production board, which at first glance does not provide such a visual overview of the status or potential bottlenecks in the production.

\section{VISUAL MANAGEMENT IMPLICATIONS}

In terms of usefulness and relevance, this model and potential VM solution provide both managers and workers with a visual link between the plan, location, and resources. This is relevant for practical implementation and decision-making. But it also contributes to the discussion Koskela et al. (2018) started of why VM. Our artifact is grounded in the planning and control of the processes. The PDCA then continuously allows managers and workers to engage in knowledge sharing, assess deviations and actions directly related to the production. These insights can then be reused to nurture skill development (Yap et al. 2020), improve productivity (Neve et al. 2020) as waste and non-value-adding activities surface and become identifiable. From an operational safety perspective, Tezel et al. (2013) argued that VM increased safety among actors as; when, where, and who becomes visual for everyone. The Takt and LBS both present task collisions or limited time buffers, which visually allow the first assessment of variability, risks, and hazards. Future research would be required to verify this and the actual effect on safety measures.

\section{CONCLUSION}

The objectives of this research were met, as the artifact engages with both managers and workers through visual expression. Illustrating the Takt or LBM schedules in a simple overview of all tasks and resources required, with identifiable pictures. The adaptation of the artifact requires an understanding of the outer environment, requiring that planners, managers, and workers collaborate on organizing the locations, task sequence, and resources. A limitation to this research was the lack of practical implementation, which allows future research to continue with the model in either modular or regular construction context where Takt or LBS is applied. Further research would be required to understand the application of the model in other project types, e.g., high-rise buildings. Or if the model could be incorporated with, e.g., "hoshin kanri" or other managerial VM solutions.

\section{REFERENCES}

Ballard, G. (2000). "The last planner system of production control." University of Birmingham, Unpublished.

Ballard, G., and Tommelein, I. (2016). "Current process benchmark for the last planner system." Lean Construction Journal, 89, 57-89.

Baskerville, R. (2008). "What design science is not." European Journal of Information Systems, 17(5), 441-443.

Brady, D. A., Tzortopoulos, P., and Rooke, J. (2012). "Using Design Science To Further Develop Visual Management Application in Construction." 20th Annual Conference 
of the International Group for Lean Construction, I. D. Tommelein, and C. L. Pasquire, eds.San Diego, California, USA.

Brandalise, F. M. P., Valente, C. P., Viana, D. D., and Formoso, C. T. (2018). "Understanding the Effectiveness of Visual Management Best Practices in Construction Sites." 26th Annual Conference of the International Group for Lean ConstructionChennai, India, 754-763.

Deming, W. E. (2000). The new economics : for industry, government, education, MIT Press, Cambridge, Mass.

Farzad, M. R., and Cameron, V. A. (2019). "Implementing Lean Visual Tools on the Closeout Phase of a Globalscale Industrial Project." Proc. 27th Annual Conference of the International Group for Lean Construction (IGLC)Dublin, Ireland, 675-686.

Fiallo C, M., and Howell, G. (2012). "Using Production System Design and Takt Time To Improve Project Performance." 20th Annual Conference of the International Group for Lean Construction, I. D. Tommelein, and C. L. Pasquire, eds.San Diego, USA.

Frandson, A. G., Seppänen, O., and Tommelein, I. D. (2015). "Comparison Between Location Based Management and Takt Time Planning." 23rd Annual Conference of the International Group for Lean Construction, O. Seppänen, V. A. González, and P. Arroyo, eds.Perth, Australia, 3-12.

Frandson, A. G., and Tommelein, I. D. (2016). "Takt Time Planning of Interiors on a PreCast Hospital Project." 24th Annual Conference of the International Group for Lean ConstructionBoston, USA.

Hevner, A. R., March, S. T., Park, J., and Ram, S. (2004). "DESIGN SCIENCE IN INFORMATION SYSTEMS RESEARCH." MIS Quarterly, 28(1), 75-105.

Hopp, W. J., and Spearman, M. L. (2004). "To pull or not to pull: what is the question?" Manufacturing \& service operations management, 6(2), 133-148.

Jabbari, A., Tommelein, I. D., and Kaminsky, P. M. (2020). "Workload leveling based on work space zoning for takt planning." Automation in Construction, 118, 103223.

Järvinen, P. (2007). "Action Research is Similar to Design Science." Quality \& Quantity, 41(1), 37-54.

Koskela, L., Tezel, A., and Patel, V. (2019). "Theory of Quality Management: Its Origins and History." Proc. 27th Annual Conference of the International Group for Lean Construction (IGLC)Dublin, Ireland, 1381-1390.

Koskela, L., Tezel, A., and Tzortzopoulos, P. (2018). "Why Visual Management?" 26th Annual Conference of the International Group for Lean ConstructionChennai, India, 250-260.

Lehtovaara, J., Mustonen, I., Peuronen, P., Seppänen, O., and Peltokorpi, A. (2019). "Implementing Takt Planning and Takt Control Into Residential Construction." Proc. 27th Annual Conference of the International Group for Lean Construction (IGLC)Dublin, Ireland, 417-428.

Lehtovaara, J., Seppänen, O., Peltokorpi, A., Kujansuu, P., and Grönvall, M. (2020). "How takt production contributes to construction production flow: a theoretical model." Construction Management and Economics, 1-23.

Lerche, J., Neve, H., Pedersen, K. B., Wandahl, S., and Gross, A. (2019). "Why Would Location-Based Scheduling Be Applicable for Offshore Oil and Gas Construction?" Proc. 27th Annual Conference of the International Group for Lean Construction (IGLC)Dublin, Ireland, 1295-1306. 
Lerche, J., Neve, H., Wandahl, S., and Gross, A. (2019). "Combining takt and Deming cycles at operator level - practical study." 10th International Conference on Engineering, Project, and Production Management (EPPM2019), Springer, Berlin, 9.

Lerche, J., Neve, H., Wandahl, S., and Gross, A. (2020). "Continuous Improvements at Operator Level." Journal of Engineering, Project, and Production Management.

Lerche, J., Neve, H. H., Ballard, G., Teizer, J., Wandahl, S., and Gross, A. (2020). "Application of Last Planner System to Modular Offshore Wind Construction." Journal of Construction Engineering and Management, 146(11), 05020015.

Lerche, J., Seppänen, O., Pedersen, K. B., Neve, H., Wandahl, S., and Gross, A. (2019). "Why Would Location-Based Scheduling Be Applicable for Offshore Wind Turbine Construction?" Proc. 27th Annual Conference of the International Group for Lean Construction (IGLC)Dublin, Ireland, 1283-1294.

Leth, S., Lerche, J., Neve, H. H., and Wandahl, S. (2019). "Lessons for Construction: Delivering Mega Project on Time Through Culture and Hoshin Kanri." Proc. 27th Annual Conference of the International Group for Lean Construction (IGLC)Dublin, Ireland, 1011-1022.

Lindhard, S., and Wandahl, S. (2012). "Improving the Making Ready Process - Exploring the Preconditions To Work Tasks in Construction." 20th Annual Conference of the International Group for Lean Construction, I. D. Tommelein, and C. L. Pasquire, eds.San Diego, USA.

Lindhard, S., and Wandahl, S. (2014). "Exploration of the reasons for delays in construction." International Journal of Construction Management, 14(1), 36-44.

Mariz, R. N., Galvao, E. L., Picchi, F. A., Melo, R. S. S., and Barcelos, M. C. B. (2019). "Daily Management Application in a Dam Construction Project." Proc. 27th Annual Conference of the International Group for Lean Construction (IGLC)Dublin, Ireland, $1425-1434$.

Mota, B., Biotto, C., Choudhury, A., Abley, S., and Kagioglou, M. (2019). "Lean Design Management in a Major Infrastructure Project in UK." Proc. 27th Annual Conference of the International Group for Lean Construction (IGLC)Dublin, Ireland, 37-48.

Neve, H., Wandahl, S., Lindhard, S., Teizer, J., and Lerche, J. (2020). "Determining the Relationship between Direct Work and Construction Labor Productivity in North America: Four Decades of Insights." Journal of Construction Engineering and Management, 146(9), 04020110.

Neve, H., Wandahl, S., Lindhard, S., Teizer, J., and Lerche, J. (2020). "Learning to see value-adding and non-value-adding work time in renovation production systems." Production Planning \& Control, 1-13.

Reinbold, A., Seppänen, O., and Peltokorpi, A. (2020). "The Role of Digitalized Visual Management to Empower Selfmanaged Crews in Construction Projects." Proc. 28th Annual Conference of the International Group for Lean Construction (IGLC)Berkeley, California, USA, 925-936.

Rocha, C. G. d., Formoso, C. T., Tzortzopoulos-Fazenda, P., Koskela, L., and Tezel, A. "Design Science Research in Lean Construction: Process and Outcomes." Proc., 20th Annual Conference of the International Group for Lean ConstructionSan Diego, California, USA.

Simon, H. A. (1996). The sciences of the artificial, MIT Press, Cambridge, Mass.

Singh, V. V., Tommelein, I. D., and Bardaweel, L. (2020). "Visual Tool for Workload Leveling Using the Work Density Method for Takt Planning." Proc. 28th Annual 
Conference of the International Group for Lean Construction (IGLC)Berkeley, California, USA, 865-876.

Tezel, A., Koskela, L., and Tzortzopoulos, P. (2016). "Visual management in production management: a literature synthesis." Journal of Manufacturing Technology Management, 27(6), 766-799.

Tezel, A., Koskela, L., Tzortzopoulos, P., Koskenvesa, A., and Sahlstedt, S. (2011). "An Examination of Visual Management on Finnish Construction Sites." 19th Annual Conference of the International Group for Lean Construction, J. Rooke, and B. Dave, eds.Lima, Peru.

Tezel, A., Koskela, L. J., Tzortzopoulos-Fazenda, P., Formoso, C. T., Alves, T., Neto, B., Viana, D., and Mota, B. (2010). "PROCESS TRANSPARENCY ON CONSTRUCTION SITES: EXAMPLES FROM CONSTRUCTION COMPANIES IN BRAZIL." 18th Annual Conference of the International Group for Lean Construction, K. Walsh, and T. Alves, eds.Haifa, Israel, 296-302.

Tezel, A., Koskela, L. J., and Tzortzopoulos, P. (2013). "Visual Management in Industrial Construction a Case Study." 21th Annual Conference of the International Group for Lean Construction, C. T. Formoso, and P. Tzortzopoulos, eds.Fortaleza, Brazil, 471480.

Valente, C., Brandalise, F., Pivatto, M., and Formoso, C. (2017). "Guidelines for Devising and Assessing Visual Management Systems in Construction Sites." 25th Annual Conference of the International Group for Lean ConstructionHeraklion, Greece, 695702.

Valente, C. P., Pivatto, M. P., and Formoso, C. T. (2016). "Visual Management: Preliminary Results of a Systematic Literature Review on Core Concepts and Principles." 24th Annual Conference of the International Group for Lean ConstructionBoston, Massachusetts, USA.

van Aken, J., Chandrasekaran, A., and Halman, J. (2016). "Conducting and publishing design science research: Inaugural essay of the design science department of the Journal of Operations Management." Journal of Operations Management, 47-48, 1-8.

Wesz, J. G. B., Formoso, C. T., and Tzortzopoulos, P. (2018). "Planning and controlling design in engineered-to-order prefabricated building systems." Engineering, Construction and Architectural Management, 25(2), 134-152.

Yap, J. B. H., Shavarebi, K., and Skitmore, M. (2020). "Capturing and reusing knowledge: analysing the what, how and why for construction planning and control." Production Planning \& Control, 1-14. 